\title{
The Queer and the Ominous: Lina Meruane's Poetics of 'Degeneration'
}

\author{
Gabriele Bizzarri ${ }^{1}$
}

\begin{abstract}
Since the adventures of her Infantas up to the 'illness in voluntary trilogy' (which is where her two major novels Fruta podrida and Sangre en elojo are framed), Lina Meruane has developed a 'degenerated' poetics, characterized by an insistence on 'bodies in progress', i.e. obsessively thematising a metamorphosis which works both as a disturbing element and as a platform for anarchy: an inscrutable source of both fear and pleasure. In fact, the body -which she inflects in a meticulous and hallucinatory inventory of variations, excesses and abjections- operates in her oeuvre like a 'deidentifying machine'. This essay aims at focusing on the peculiar intersection which seems to explain effectively the unstable living forms that inhabit her texts, one where queer discourse (in all of its rhizomic ramifications) mixes with fantastic and gothic features. If, on the one hand, Meruane's political agenda clings to the refusal of the disciplinating mould and the objection to any request of identity accountability, on the other, in souciantly flirting with the narrative codes of the ominous, the Chilean writer counterbalances her revolutionary theoric drive, as it is illustrated by the estranging, almost 'horror' staging she intends for everyone of her ambiguous, amorphous creatures.
\end{abstract}

Keywords: Identity. Displacement. Lina Meruane. Queer. Fantastic Fiction.

\section{Introduction}

With almost three decades of queer studies behind us, it could be superfluous to mention that the epistemological scope of this critical guideline has become more and more hard to limit in the ghetto of LGBT dissidence: that is, at this point, precisely the automatic identification of the queer with certain groups and certain topics has begun to productively crackle. And yet, the application of that increasingly slippery label -one which, nevertheless, goes on carrying the burden of the gender's long and adventurous history of emancipation- to the poetics of Lina Meruane still requires some previous clarification, especially if we consider the two self-fictional novels that are included in her self-proclaimed involuntary trilogy of disease'.

\footnotetext{
${ }^{1}$ Università degli Studi di Padova. gabriele.bizzarri@unipd.it ㄴo https://orcid.org/0000-0001-9835-9449.
} 


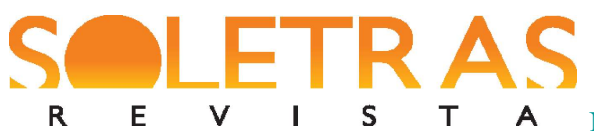

N. 38- 2019.2- GABRIELE BIZZARRI

Both Sangre en el ojo (2012) and Fruta podrida (which precedes it in 2007), in fact, struggles to verbalize two anomalous bodies - the fragile 'plots' inhabited by the diabetic aliases of the author, blurred and alienated precisely by the outbreak of the disease, which opens them to uncertainty and turns them into powerful politically resistant devices who speak against the laws of accountability-, but they do so, in one case, from within a more or less 'standard' heterosexual relationship and, in the other, from the pre-sexual body of a child, a 'younger sister', apparently neutralizing the variables of sex, gender and sexuality. But in both cases disease is the stratagem that the author uses to dismantle the identity of the Subject, to expropriate -in an entropic outburst where masochism and sadism are linkedeach and every one of its sociocultural alibis, treating it as an undifferentiated flou, turning it into something dangerously unshaped and menacingly mobile, always in trance of being something else, of not being of anyone, of being nothing -obviously marking a path which puts a strain on the asset of norms that define what we know as sociability and irritates the (nervous) system ${ }^{2}$ of the 'collective body'.

In this way, Lina Meruane has developed what I call, in more than one sense, a degenerated poetics, characterized by the obsessive insistence on the motive of transformation, by the thematization of a metamorphosis ${ }^{3}$ that serves, at the same time, as a disturbing element and an incentive for anarchy, a source of both pain and pleasure (or, in lacanian terms, a source of jouissance). A poetics where the body -that Meruane visionary and ambivalently observes in a disconcerting repertoire of alterations, overflows and abjections- seems to work as a 'de-identifying machine'.

If the theoretical debt with the queer of the identity policy that radiates from disease in the narratives of the Chilean writer becomes explicit in Viajes virales (2012) -the third element of the trilogy, which Meruane dedicates to the Latin American literature of $\mathrm{AIDS}^{4}$-, that filiation, indirect, yet not less productive, does not cease to peer fiercely and with

\footnotetext{
${ }^{2}$ Sistema nervioso(2018) is the title of Meruane's latest novel, which, in fact, turns the so-called trilogy of the sick body into a tetralogy.

${ }^{3} \mathrm{We}$ could spot the motive of metamorphosis as an (in)natural stitch point between the queer theoretical line and post-human studies. SeeBraidotti (2005).

${ }^{4}$ The essay is based on the author's PhD dissertation, the same one that, in Sangre en elojo, Lina Meruane's fictional alias stops writing when she becomes blind. Both in fiction and in real life, her supervisor is Sylvia Molloy, whom the reader is called to recognize not only as "otra experta [más] en los horrores del cuerpo" (MERUANE, 2017, 154), but also as one of the great pioneers of sex-dissident literature in Latin America, as much due to her narrative oeuvre (En breve cárcel) and because of her critical investigation, being her Poses de fin de siglo one of the most eloquent essays on the topic of different sexualities in the context of Latin American 'modernism'.
} 


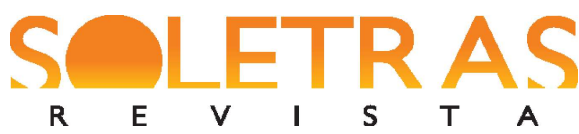

N. 38- 2019.2- GABRIELE BIZZARRI

thematic precision between the folds of the plots of the two novels, with collateral episodes, winks and allusions that persistently seek for the ill body precise complicities with the sexually nonconformist one.

Indeed, the queer code is the rough material with which the two metaphors that direct the mechanisms of the signification are mingled: the blind eye and the rotting fruit.

\section{Displacing the gaze}

The protagonist and narrator of Sangre en el ojo ${ }^{5}$, facing her blindness, kills, causes the disappearance of one Lina Meruane (in the melting-pot of the self-fiction), becoming her unseeing double, something like a lightless Lina that, despite this, is named Lucina, adding a luminous prefix that not only works as a paradoxical rhetorical device cast in tragic irony, but rather, textualizes, inscribes in the text -safe from any essentialist suspicion- the real first name of the writer ${ }^{6}$, ambiguously alluding to the threat of a return, to the reunion of the traumatized self with certain obscure properties and forgotten knowledge, fully denied in the process of pursuing a 'diurnal' identity. In other words, beside what the character is afraid to lose -violently rejecting a violation of her completeness ${ }^{7}$ that makes her move clumsily between blunt objects, immovable bodies and relationships corseted by unbreakable patterns and models, and stubbornly trying to recover her right 'vision'-, there slowly emerges the ambiguous gain of a one-eyed vision (call it a blurred clairvoyance, intercepting a mythical genealogy, or call it a 'queer eye') that reveals a drifting, shapeless world, in whose fading, placental fringes, Lucina's sharp analytical consciousness manages to get lost at times.

The insistent descriptions of the 'stain' produce some of the most intensely lyrical passages of the book: in that black night inhabited by lumps, in that dazzling absolute white, in those entangled hallucinations of veins and capillaries, in that aquarium crossed by improbable bubbles and corpuscles negotiating filamentous transactions and languorous shipwrecks, in that psychedelic kaleidoscope in which the multiplied forms and the crooked

\footnotetext{
${ }^{5}$ About this novel, see Fallas (2012), Fenna Walst (2015) and Oreja Garralda (2018). On the specific topic I discuss here, see also Mancilla (2017), who focuses entirely on monstrousity.

${ }^{6}$ In the manner of one 'diamelaeltit' - with lowercase -, which is textually born in the very last lines of the novel El cuarto mundo.

${ }^{7}$ As it is known, vulnerability is a key-word in the queer alphabet. See Butler (2004).
} 


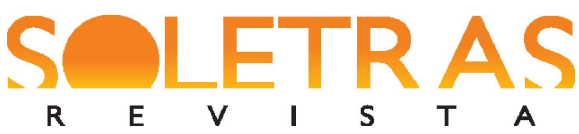

N. 38- 2019.2- GABRIELE BIZZARRI

perspectives are those who triumph -just a delightfully off-key note in the severe background of fear-the feeling that another way of looking ${ }^{8}$ is possible begins to surface. And this possibility might have to do with the scopes and the very intentions of the fictional (or selffictional) word, in its implicit aggression to the fetish of the real: "esto se parece a ver", says Lucina, "pero es mucho más que estar viendo" (MERUANE, 2017, 159).

As in "El Ojo Silva" by Roberto Bolaño, the declassification of identity -helped, in one case, by a physical disability, in the other, by a different sexuality- calls for the acquisition of a visual idiosyncrasy that delves beneath the pure, diaphanous, perfectly intelligible forms that we are obliged to cast to be socially recognizable, exposing all the fragility -or better, the violence- which is inherent to our performances of ordinariness.

In the chapter of the novel entitled "pagar el debido precio", Lucina seems to seal the pact of complicity that we have been describing, finding - above and behind any scientific, physiological basis - a symbolic link between her diabetic blindness and AIDS, and feeling reflected in an old 'sissy' who, very significantly, is about to sell a lamp to her and her boyfriend: his infarcted eye, his "ojo en blanco" (MERUANE, 2017, p. 34) - an opaque and ambiguous mirror for a character who's living the early stages of her traumatic walk through darkness - tells Lucina the story of the plague that, in the eighties, made havoc among "sugente" (MERUANE, 2017, p. 34), working at the same time as a stigma and an amulet.

It is also the signal that indicates that the internal balance within the couple is going to get broken, that its correspondences and fittings are getting twisted, that - so to speak - the legs of the matrimonial double bed are beginning to limp a little, as it's evident in the disturbing scene of oral sex - that opens in fact a series of sequences based on the literal eroticization of Ignacio's eyeballs - in which Lucina eagerly sucks a "lágrima" from "la punta de su cuerpo, como si fuera eso lo que más me excitaba"(MERUANE, 2017, p. 92): what's beginning to creak - by means of a grotesque deformation - is the performative model of the heterosexual couple, with the obliging abnegation of the perfect gentleman and the female clinging like an ivy-parasite to the stick of her guide, until she suddenly ceases to be impressed with the "vidrios de colores" of her "conquistador de segunda" (MERUANE,

\footnotetext{
${ }^{8}$ Insistently comparing her crooked eye with a fantastic fish bowl, Lucina seems to be quoting directly from Cortázar' "Axolotl", claiming for herself the terrible teaching that comes precisely from the eyes of the larval creatures that obsess the narrator of that short story, the ones who ultimately rob him of the possibility of being just 'him' and therefore reveal "la presencia de una vida diferente, de otra manera de mirar" (CORTÁZAR, 1994, p. 202).
} 


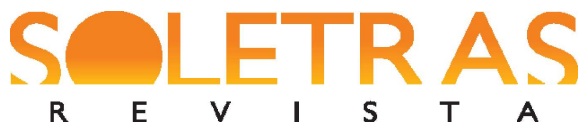

N. 38- 2019.2- GABRIELE BIZZARRI

2017, p. 86) and goes for his "eye", suggesting a symbolic castration that neutralizes the marker -and the social consequences- of the unpaired chromosome.

\section{Displacing the sense of territory}

Turning to Fruta podrida ${ }^{9}$ - without a doubt, the most extreme of the two narratives with regard to the construction, through illness, of a body-manifesto that, abdicating the disciplinary obligation of therapy, lives (and dies) clinging to its libertarian disarray-,Zoila del Campo, one of the two stepsisters who inhabit El Ojo Seco's orchard - to be more specific, the one that turns 'one-sided' the economic gaze of the family company - conceives her organism as a spontaneous fruit between rows and crates of clonal ones, designed from and for the production system, and carries out, throughout the novel, a disturbing performance that is a true homage to rottenness. With the help of an index of poetic figurativity of the highest order, her diabetic body rots along the novel enjoying every single moment of its sweet fermentation, losing 'definition', exceeding the mold, until it releases all of its juices without containment or shame, leaving everywhere libidinous stains, and finally finding, precisely in the loosening of the undistinguished matter, the expression of its own individuality (Soy-la, with an s-, as in 'I'm the one'). The morbid eroticization of the bodystain leads to the impression of a defiantly unproductive pregnancy ${ }^{10}$ ("pese a la delgadez que provoca mi extrema dulzura, estoy aumentando bajo la ropa, me redondeo por todos lados", MERUANE, 2015, p. 81), or a differently productive one, for Zoila recalls, at times, a goddess of withered fertility, overflowing with dark living forms, covered in fungi, full of worms, perennially surrounded by a swarm of 'vampire flies' - the same that insert "sus larvas dentro de [las] manzanas, ciruelas y uvas que la nutren" (MERUANE, 2015, p. 76), virtually turning the precious harvest of the older sister into waste for the landfill. When she becomes aware of the mortal threat represented by the insect that seems to live in a state of symbiotic interpenetration with the younger one - at the same time feasting with the mouldy pulp of her flesh and being generated from it in a vicious circle of paradoxical dead

\footnotetext{
${ }^{9}$ On this novel see Ferrús (2016) and Francica (2017).

${ }^{10}$ One of the defiant transvestites that inhabit Pedro Lemebel's sidario -the dying Loba Lámar, her body monstrously swollen by the juices of the disease-isdefined in the chronicle that sees her as the protagonistas "preñada de naufragio" (LEMEBEL, 1997, p.44).
} 


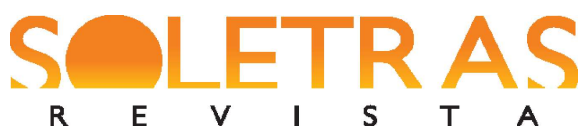

N. 38- 2019.2- GABRIELE BIZZARRI

productivity, a 'dry eye' that germinates its own ill-fated harvest-, María, invoking a pseudoscientific argument, gives 'the plague' an African origin and the shape of a promiscuous and cosmopolitan traveler, quoting thus, almost literally, the cultural narrative of AIDS and its metaphors -the same one that, in Viajes virales, Lina actually eats up raw, proceeds to digest and, ultimately, gets rid of. In this way, the queer genealogy of Meruane's patients is reconfirmed, all of them carriers of the threat of an 'infectious sterilization' of the (economic) system that regulates our behavioral patterns, and consequently, restless explorers of other possible ways of life, adventurers in an alternative relational environment. Zoila's body - which, from within the heteronormative law, is also described as a dry shell, "el puro armazón de un insecto [...] vaciado" (MERUANE, 2015, p.15) - contrasts with the matrixbody of (Santa) María del Campo, the tireless reproductive machine, whose version of the motive of monstrous motherhood (with a medical-dystopian science fiction allure) is obtainedby emphasizing (not too much) the features that would correspond to the feminine role in a rural economy model (taken out of control by the neoliberal import). From here to the queer apocalypse, to the No future theorized by Lee Edelmann (and obviously to the symbolic genocide proposed, from a feminist and an anti-capitalist perspective, by Meruane herself in Contra los hijos) the step is very brief.

This suggests a clue for the interpretation of that eerie and theatrical finale in which, in front of the façade of the Great Northern Hospital, accompanied by a tragic chorus of blind beggars, the Elder Nurse and her social nemesis - the saboteur, the terminally ill who evades any therapeutic protocol- finally face each other in an ambiguous role-play, where the two main characters, receiving the echoes of multiple different parts, seem to act, respectively (but also interchangeably), as a victim and an executioner, a criminal and a police officer, an informant and a detective, a fool and a sane, a daughter and a mother, an undocumented visitor and a legitimate resident, Lady Death and her lover... until they finally realize they are identical doubles and their dialectical contraposition reveals itself as a mere rhetorical device which hides the 'bloody nothingness' that unites them (and us all) in a perfect match. Becoming completely impossible to know where the one ends and the other begins, both are brought together in a viscous and definitive fusion that denies every name and erases every sign of identity, at the same time as, most significantly, the hand of the woman in uniform who, inexplicably, never tries to aid her dying partner - begins to delve into the rotten leg of 


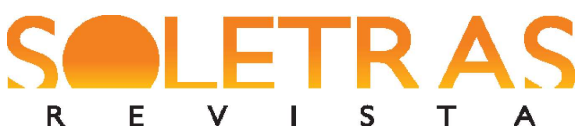

N. 38- 2019.2- GABRIELE BIZZARRI

the diabetic, making her way "por la estrecha ranura", breaking through that wet and slippery pulp (MERUANE, 2015, 204), guided at the same time by an incipient cupio dissolvi and by the inquisitive nature of desire, until Zoila dies in her arms in a doubly feminine and insouciantly erotic set ${ }^{11}$.

\section{Portrait of the artist as a young monster}

If all of the above was not enough to characterize the writing of Lina Meruane within a line of intervention that critical literature has not yet highlighted with enough strength ${ }^{12}$, the possibility of comparing those two 'ill' endings with that of her first published book -Las Infantas (1998) - gives the chance of closing with a flourish, activating, in addition, the second point I would like to stress, that is, the gothic aftertaste, the terrifying nuance that emerges from the representation of the bodies (also sexually) anomalous throughout her whole trajectory. Indeed, here, those elements, benefiting from a less realistic fictional environment, unveil their referents, inserting themselves in a precise genealogy: the adventures and mischiefs of the two princesses who star in this deranged fairy-tale - almost a 'decolonized' rewrite, in death of the Father's law, of the Perrault tradition, in the vein of Luisa Valenzuela's Simetrías ${ }^{13}$ - lead to a Sapphic and incestuous marriage, in which a Snow White increasingly hungry for her sister's saliva manages to awake, by virtue of the magic of her tongue, the Sleeping Beauty from the grave ${ }^{14}$. In a last libidinous outburst that is also a black ceremony, virtually transformed into vampiric creatures, the two nymphs 'take communion' with the body of a priest, nailing a crucifix in his heart by way of a climax. The fact that the point of maximum erotic intensity - the happy ending of this tale of liberation

\footnotetext{
${ }^{11}$ This link seems to be shaped as a nihilistic and lesbian rewriting of the sexual and economic understanding established between the older sister and the sinister male nurse of the peripheral hospital; their hygienic, faceless progeny -the children of the future of the founding couple, oiling the system's machinery- is programmatically designed for the market and, literally, quoting Diamela Eltit, "irá a la venta" (2011, p. 245). It should also be noted that, in the version of the novel published by the Fondo de Cultura Económica, in an episode that has been suppressed in the Eterna Cadencia edition, just before Zoila is going to exceed also the borders of the Nation and cross to the United States like an undocumented inmigrant, her and her older sister finally seal a fraternal pact of insumission with, of all things, a sapphic kiss.

${ }^{12}$ I could only find one work that mentions the queer referring to Meruane's literature and it precisely deals with Las Infantas: within a broader case of examples, Lucía Punte dedicates a suggestive section of her article (2013) to the Chilean writer ("El deseo crece: para una lectura queer de Las Infantas de Lina Meruane").

${ }^{13}$ About this, see Oreja Garralda (2017).

${ }^{14}$ Correspondingly, the princess's 'intoxicating' breath no longer smells like wall flower but has matured an acidic fetidity: that of diabetic coma.
} 


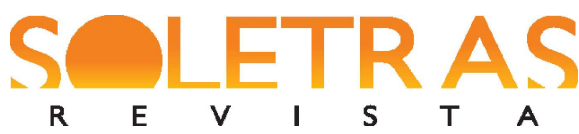

N. 38-2019.2- GABRIELE BIZZARRI

from the patterns of the genre and the gender - takes place in a fresh burial, where the indistinct matter lingers, promising to spoil our contours - a space that, I should add, is part of a sequence of analogous 'hiding places' suitable for the maturation of a 'different'desire: the deep undergrowth, with its intense smell of earth, damp and stale like that of the girls' panties; burrows; dark cellars, covered in mold and full of rats, that snaking and collective body-in-progress etc. - does nothing but confirm a coherent and obsessive metaphorical systemthat finds here - in this true seedbed of degenerations that, later, Meruane will struggle to enroll in the symbolic order - its most archetypal expression, with the tropes of the rot and the empty eye entangling the paths of pleasure and horror through the narrative wood.

That second thread is also to be pulled, the one that injects blood into the antinormative projection of the 'queer eye', bathing in cold sweats both its creatures and those who contemplate them. As a matter of fact, this paper tries to find the core of Lina Meruane's poetics precisely in the disquietly mobile intersection that occurs between the queer discourse (with all its constellation of opaque stars: the 'vulnerable', the 'androgynous', the 'in transition', the 'post-human' also ...) and the 'ominous-fantastic' one: where on the one hand the political agenda of Meruane's narratives refers to the rejection of the closed form and to the questioning of the "category-bound activities" 15 that define our identity and we are trained to recognize, authorize and claim as our own, the overlapping flirtation with a certain macabre repertoire which systematically helps her to express those dangerous infringements to the norm (a long theory of 'host-creatures', transformed beings and undistinguished 'human things') works as a counterweight, provoking an estranging, sinister, almost horror staging of the revolutionary results evocated by the theoretical thinking. It is as if before the crawling intensity of the 'indistinct life', before those strange and blurred living forms that are her political matter, Lina's sight turned black, or better, 'deep red', as evidenced by Zoila and Lucina, two self-fictional monsters, whose "excesses of the body" (GUERRERO, BOUZAGLO, 2009) - i.e. the basilar tools of identity experimentation in the whole trilogy-, very understandably, are also horrors, textualized biographical fears.

But in reality it is in Las Infantas that this violent vein explodes, because the ignition of the young girls' desire for what is extravagant, deformed, non-exemplary (or, in its most extreme incarnation, obscenely undistinguished) actually awakens a true catalog of atrocities.

15 The expression comes from the sociolinguist Harvey Sacks, whom, in a sense, despite working on conversation's analysis, we can identify as a true pioneer of queer studies. 


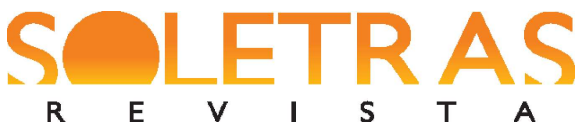

N. 38- 2019.2- GABRIELE BIZZARRI

And I do not refer so much to the main plot, where all truculence and perversion related to their rebellious search (cannibalism, bestiality, necrophilia etc.) are only the occasion for a grotesque feast, a childish and mischievous sadistic game, but rather to the eleven short stories that interrupt this queer hyper-fable, distorting disturbingly each of the libertarian achievements of the primary story.

Indeed, we can highlight two very different series of horrible features in Las Infantas. In one of the strangest passages of the emancipatory adventures of the two little princesses who, rejecting all identity crystallization, jump, with overwhelming ease, from one fairy-tale to another, reformulating themselves as "trozo[s] de masa" (MERUANE, 2010, p. 40) - the older one channels her incipient erotic appetite towards a strange creature of the forest, a "animal herido", a "pastel de carne" (MERUANE, 2010, p. 40), a "bola de pellejo que se movía emitiendo gemidos apenas perceptibles", still tied by the umbilical cord to the "enredo de larvas palpitantes" (MERUANE, 2010, p. 34) that must have been its mother. The girl, "excitada por el descubrimiento", takes on the role of an avid dominatrix, severing the original bow with her pointed fingernail and licking lustfully "el chorro oscuro", "el espeso fluido" with oyster flavor (MERUANE, 2010, p. 34 ), and proceeds to turn the monstrosity into her puppy, a sex toy, one of the many possible avatars (of the rejection) of a Prince. The eschatological debauchery of this sequence matches with a surrealist ascendancy, recalling André Breton and Luis Buñuel's cruel hallucinations (how not to bring up here that inaugural eye cut with a razor blade?), going through Maldoror's 'maravilloso negro', which of course impacts in Marosa di Giorgio's bestial panerotism ${ }^{16}$..., in short: a whole tradition of artistic derangement, sensory exhaustion and decomposition of the poetic form(s) that is here made flesh in order to sustain an inclusive politics of the degenerate body. The presentation of these motifs in the plot that concerns Hildeblanca and Hildegreta's forays in the unknown neutralizes the violence of what's unusual (no matter how brutal, ferocious and repulsive its manifestations may be), dispersing its possibly ominous effects in a program of unadulterated, joyful provocation, a defiant cult of the outrageous that does not admit codes of contrast nor resist a shadow of a hesitation.

On the contrary, in the small cycle of queer terror short stories that also opens in these pages, the unusual body - which is made custody of an imaginary at once rabidly denied and

16 Precisely from a queer perspective, Roberto Echavarren (2007), referring to the Uruguayan poetess' hallucinatory world, coins the definition of "out of gender". 


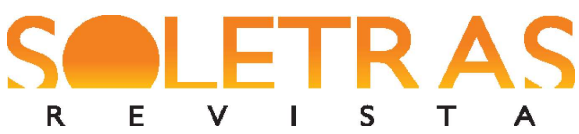

N. 38- 2019.2- GABRIELE BIZZARRI

obsessively attractive - becomes a restless receptacle of tensions, a problematic surface crossed by alternating currents of indistinct drives, in the presence of whose menacing ambivalence the world of the norm is called to face its own state of exception. At any rate, something dangerously unresolved, a paralyzing riddle: a 'ghost', it would be said, if we were still gagged by an illuminist rhetoric instead of the narrowness of the biopolitical discourse, and the supernatural still represented the most outrageously unacceptable, the most pressing drop point of our societies.

What stands behind, in “cuerpos de papel”, Renato's toothless, smelly mouth, the obsessive fetish of the junkman whom the female narrator is obsessively waiting for every Thursday at midnight ready to exchange with him squalid sex sessions for recyclable waste bags (yellowed newspapers, locks of her own hair ...)? What does Meruane intend to verbalize with this perverse chain of exploitation? Perhaps a revealing short circuit of the system, one that discloses how the trade of indistinct matter is the common territory through which both the erotic and the economic flux circulate? In any case, that "oquedad [...] pestilente" (MERUANE, 2010, p. 96), thematically linked to the garbage dump which addresses the defenselessness of the suburbs, is the place where derailed desires and death drives meet, is a rabbit hole, a blind spot (a blank eye), a primordial vagina - as it seems to indicate, in the end, Renato's 'transformation' into a woman -, and eventually, summarizing all of the above metaphors, is also Chtulhu.

Generalizing, the trigger for violence, what actually releases the disturbing effect in all of these interpolated stories is the pressure applied by the model, the echoes of social discourse sneaking through the cracks of the most alternative complicities and the most 'aberrant' of the pacts, that is: the laws of 'natural' conformity, affecting both those who suffer from the vertiginous attraction toward what is asymmetric and unproductive-who, in fact, feel obliged to exorcise their own obscene objects of desire, trying to re-plasm them into a decent pose, turning off their disturbing spell behind the façade of a 'common name'- and, on the other hand, the derogatory body itself, which often internalizes its insolvency and, beginning to feel as an incomplete and inopportune form, starts to get poisoned by an unattainable ambition of regularity, becomes obsessed with the desire to please or seduce the right eye of the watchman and, consequently, ends up being an herald of apocalypse for the world that excludes it. 


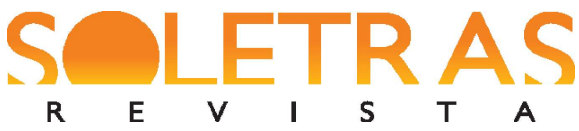

N. 38- 2019.2- GABRIELE BIZZARRI

This is the case of the two short stories that seem to be conceived as improper rewrites of the Pygmalion myth (perhaps by hybridization with that of Frankenstein), both told from the point of view of the prodigy - the asymmetric body, the body-thing - which, in the first example, becomes the victim of the modeling delirium of the Demiurge Artist and, in the second, triggered by its jealousy towards the natural prototype, the underlying desire to compete with the original, destroys the perverse order that has generated it as the Other.

In "grabado sobre lámina", a plastic artist aspires to satisfy (and at the same time turn off) her obscene desire for a discarded creature, a dwarf with a prominent hump, using him as a living model to reproduce the perfect profile of her former lover, thus disguising her caresses behind the alibi of "mediciones precisas que anotaba en sulibreta"(MERUANE, 2010, p. 48) ${ }^{17}$ : "Cuanto te pareces a él, enano. A veces pienso si acaso podría. Contigo" (MERUANE, 2010, 49).

Intercepted by the interdictions of the code, this flirtation with the untouchable nuda vita turns into an obsession for the definitive oeuvre, for eternalizing in a incorruptible sheet the sacred rictus of conjugal love, with the liberated and decomposed matter - and its dark, unacceptable appeal - serving as a dough or a necessary glue. Thus, the "producción experimental" (MERUANE, 2010, p. 49) becomes a biopolitical experiment and in the great alchemical pot of the 'witch', together with the stinking wastes of "zanahoria, alcachofa, acanto, lirio [y] ajo" withering (MERUANE, 2010, p. 50), the detached elements of the fetish (the skin, the hair and the sperm of the dwarf) also merge, until the whole of this man-like receptacle of the most unclean and unspeakable desires retreat to the status of a mere abject mass, finally hidden under the triumphant reproduction of the straight model, turned invisible in the icon:

No recuerdo haber sentido nada más, nada en absoluto, ni siquiera la punta de las tachuelas que me clavó para sujetarme al tamiz. Tampoco el sol de la tarde ni la brisa nocturna que terminaron por secarme para siempre en la ventana (MERUANE, 2010, p. 55).

\footnotetext{
${ }^{17}$ The connection between the figure of the dwarf and the unleashing of the sexual impulse is confirmed by the segment of the pilgrimage of the two infants that precedes this particular short story, where Princess Hildeblanca accompanies her fledgling desire with the activity of "trazar desnudos de enanos"(MERUANE, 2010, 43).
} 


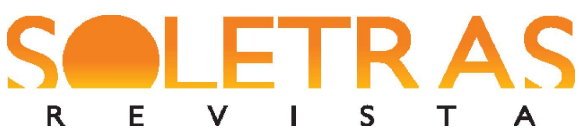

N. 38- 2019.2- GABRIELE BIZZARRI

A glass eye "rueda por encima del papel" and "se topa con una piedra sobre el cemento" (MERUANE, 2010, 63), leaving its owner one-eyed. It is one of the damages -in fact it is the primary one, the original sin- that identifies the doll called Manekine among the other members of the collection, her faultless "hermanastras", all of them improved copies of the firstborn. If the unpolluted proliferation of the series that she leads transmits a disturbing sense of miseryto the 'original matrix", "la única de proporciones alteradas, carente de simetría" (MERUANE, 2010, p. 64), it is discovering herself as a mere copy of a 'Manekine' in flesh and blood -whose comeback alienates herfrom her Father's (i.e. the supreme maker's) 'special attentions'- what will torture her to the point of channeling her steps towards the extermination of the (performative staging of the) perfect parental couple. There, in the meantime, the new queen, the self-proclaimed stepmother, seems to be determined to correct all of the spoiled girl's whims. Performativity theories and horror cinema go hand in hand in this doubly cruel tale in which what stands out is the nominal construction, the social fabrication, of relational roles; moreover, the boundaries between the norm and the exception blur considerably, since the primary scene that the devious, immature eye of the murderous doll does not resist - that of adult sex, of the 'natural' desire between a proper man and a proper woman, healthily cured from the obsession of the fetish -, hints at the suspicion of an incest between a father and his (carnal) daughter.

And despite it all, the creature betrayed by the simulation of the legitimate status, the scam of what is necessary, cannot but carry (and suffer) the weight of her shameful dysfunction, remaining romantically waiting for a Prince to sort her out, for a Doctor to release her pain, for her 'Father' to return her "ese ojo fundido por el fuego" (MERUANE, 2010, p. 70).

This path - one that implies the sickly double nature of what's supposed to be 'normal', by showing that the most terrible monsters are in fact lurking in the cast, as a vice inherent in the same idea that there should be a model, an original and an origin 'from where' we measure and stigmatize any alteration -, reaches its logical conclusion in the most revealing among all the short stories entangled in Lina Meruane's first published book, "cuencas vacias", the underground source from which the two great images of degeneration that inhabit her major novels seem to take origin. 


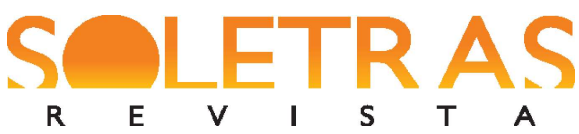

N. 38- 2019.2- GABRIELE BIZZARRI

There, a daughter is back to her childhood's house only to find the corpse of her motherburied under the floor of the parental room, covered in the "oscura sustancia" (MERUANE, 2010, p. 107) that flows from an old anthill, among garbage bags "llenas de manzanas demasiado dulces" (MERUANE, 2010, p. 109). This hypnotizing discovery suggests a more than eloquent image of the domestic temple (with its apparatus of generative rituals), actually blurring its coat of arms, and connoting it instead as the irradiation center of all fears and perversions. In a finale that could be read in parallel with that of Fruta podridaand, in addition, also seems to invite the main character of Sangre en el ojo to the macabre feast-, the protagonist begins to rummage blindly, "con las manos llenas de barro, de tierra pulposa", "en lo que queda de ese cuerpo", "del rostro sin ojos de mi madre"(MERUANE, 2010, p. 113).

If there was something to correct (an optical defect, a sexual deviation...), surely there would be no chance of seeking any guidance or tutoring here. Or perhaps yes, precisely accepting to become one with the confusion of our childhood, with that indisputable tangle of productively mixed meanings and sensations, burying us alive in the anarchy of those distant, lucid nightmares, returning to when ambiguity belonged to us as a natural right, before we had learned to separate with discernment pleasure from fear, possible from impossible, purposeful from useless, managing our lives as heritage legacy.

In the distant dialogue between the parricidal doll - who, nevertheless, was still dependent on the principle of paternal authority that made her a 'disabled body'- and this 'revenant' creature that discovers - or rediscovers- the obscene putrescence which consumes the pillars of the patriarchal house, the reader is invited to witness an eerie match: the one 'filial identities' are called to play against their parents' spectra, for the sake of whose representation, disturbingly creepy but also politically crucial, Lina Meruane does not spare us from any of the bloodied scars printed by the strict, orthopedic eye of the ancestors on the backs of those variably anomalous corporeities.

\section{References}

BOLAÑO, Roberto. Cuentos. Barcelona: Anagrama, 2010. 


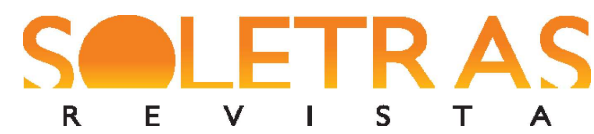

N. 38-2019.2- GABRIELE BIZZARRI

BRAIDOTTI, Rosi. Metamorfosis. Para una teoría materialista del devenir. Madrid: Akal, 2005.

BUTLER, Judith. Precarious Life. The Powers of Mourning and Violence. New York: Verso, 2004.

CORTÁZAR, Julio. Los relatos. 1. Ritos. Madrid: Alianza, 1994.

ECHAVARREN, Roberto. Fuera de género. Criaturas de la invenciónerótica. Buenos Aires: Losada, 2007.

EDELMAN, Lee. No al futuro. Barcelona: Egales, 2014.

ELTIT, Diamela. Tres novelas, Fondo de Cultura Económica: México, 2011.

FALLAS, Teresa. Sangre en elojo: víctima y victimaria encarnadas en una misma persona. Revista Estudios, 29, 1-24, 2014.

FENNAWALST, Simone. Ficciones patológicas: la enfermedad y el cuerpo enfermo en Fruta podrida (2007) y Sangre en elojo (2012) de Lina Meruane. Revista Estudios, 31, 1-18, 2015.

FERRÚS, Beatriz. Fruta podrida. La escriturades compuesta de Lina Meruane. Rassegna iberistica. 39(106), 325-336, 2016.

FRANCICA, Cynthia. Devenires de la corporalidad femenina en Fruta podrida (2007) de Lina Meruane: toxicidad, memoria y exterminio. Estudios filológicos, 62, 59-78, 2018.

GUERRERO, Javier; Bouzaglo, Natalie (eds.). Excesos del cuerpo. Ficciones de contagio y enfermedad en América Latina. Buenos Aires: Eterna Cadencia, 2009.

LEMEBEL, Pedro. Loco afán. Crónicas del sidario. Santiago de Chile: Lom, 1997.

MANCILLA, Juan Manuel. Enfermedad y monstruosidad en Sangre en elojo de Lina Meruane. Kamchatka. Revista de análisis cultural, 10, 197-215, 2017.

MERUANE, Lina [1998]. Las Infantas. Buenos Aires: Eterna Cadencia, 2010.

. Viajes virales. La crisis del contagio global en la escritura del sida. México: Fondo de Cultura Económica, 2012.

. [2007].Frutapodrida. Buenos Aires: Eterna Cadencia, 2015. . [2012]. Sangre en elojo. Barcelona: Random House, 2017. . [2014]. Contra loshijos. Barcelona: Random House, 2018. . Sistema nervioso. Buenos Aires: Eterna Cadencia, 2018.

OREJA GARRALDA, Nerea . Las Infantas de Lina Meruane: un tejido de tradiciones revisadas bajo la estética neobarroca. Lejana, 10, 101-22, 2017. 
- «Sangre en elojo: reflexiones en torno a la enfermedad, la (post)memoria, y la escritura». Perífrasis, 9(18), 80-97, 2018.

PUNTE, María José. El retorno a los bosques encantados: infancia y monstruosidad en ficciones del Sur. Aisthesis. Revista chilena de investigaciones estéticas, 54, 287-301, 2013.

SACKS, Harvey. Lectures on Conversation (2 vols.). Mlden MA: Blackwell, 1995.

VALENZUELA, Luisa. Simetrías. Buenos Aires: Sudamericana, 1993.

\section{O 'queer' e o sinistro. A poética da 'degeneração' de Lina Meruane}

Resumo: Das andanças das suas Infantas à 'trilogia involuntária da doença' (da qual formam parte as suas duas novelas maiores: Fruta podrida e Sangre en elojo), Lina Meruane vem desenvolvendo uma escrita da deslocação e da 'degeneração' caracterizada pela tematização obsessiva de uma metamorfose que funciona quer como elemento perturbador, quer como estímulo para a anarquia, causador do medo e do prazer. De facto, nas suas descrições, o corpo -visionária e ambivalentemente observado através de um repertório desconcertante de alterações, excessos e abjeções-funciona como uma autêntica 'máquina para des-identificar'. Este estudo pretende concentrar-se na intersecção inédita que melhor parece dar conta das formas estranhas e instáveis que habitam cada uma das suas fábulas e, ao mesmo tempo, as definem fora do sistema dos géneros: a que se produz entre o discurso 'queer' (com todas as suas ramificações e metáforas: o 'aberto', o 'vulnerável', o 'pós-humano'...) e o discurso fantástico (banhado em humores góticos) que também as atravessa. Se, por um lado, a agenda política dos textos de Meruane remete para a recusa da disciplina da forma e para a contestação de tudo o que é identitariamente estabelecido, o jogo constante -ainda que ambíguo-com os códigos narrativos do funesto parece servir à escritora chilena de contrapeso, levando-a a apostar numa encenação alheadora, sinistra, terrorífica até dos resultados revolucionários realizados já desde a teoria.

Palavras-chave: Identidade. Deslocação. Lina Meruane. Queer. Fantástico.

Recebido em: 25 de julho de 2019 .

Aceito em: 12 de agosto de 2019. 